\title{
HOW THE EU DEFENDS ITS NON-TRADE OBJECTIVES BEFORE THE WTO: AN ANALYSIS OF SPS/TBT DISPUTES
}

\begin{abstract}
Ferdi De Ville*
Summary: The European Union is at the same time one of the staunchest defenders of a liberal and multilateral trading order and often the most radical regulator in protecting the health of citizens and the European and global environment. This might be problematic when 'protective' regulations at home are perceived as 'protectionist' measures abroad. This article looks at a particular arena where the EU has to confront this potential contradiction: the World Trade Organization's dispute settlement system. How does the EU reconcile its free trade ambitions with its regulatory stringency there? It is found that the EU manages to act consistently before the WTO courts by refraining from pressing charges against other countries' sanitary and phytosanitary and technical measures and, as a third party, speaking out for the defendant by advocating discretion in deciding on and maintaining the appropriate level of protection. That the EU is so much on the 'protection' side of the continuum before the WTO courts is explained by its own early losses in some high-profile, sensitive WTO disputes in combination with the more risk-averse stance of the European public.
\end{abstract}

\section{Introduction}

The European Union (EU) is, at the same time, a staunch believer and supporter of free trade and multilateralism and the most radical protector of the health of its citizens and the European and global environment. Inevitably, these two positions sometimes clash. An extensive literature has addressed the question of how the EU tries to solve this conflict. According to many observers, the EU tries to 'export' or 'upload' its ambitious regulations so that it attains its regulatory objectives and at the same time assures the free flow of goods and the competitiveness of its businesses. ${ }^{1}$ According to others, this argument is overstated. They argue that the instances where EU regulations are significantly affect-

PhD, Assistant Professor, Centre for EU Studies, Department of Political Science, Ghent University.

1 See D Vogel, Trading Up: Consumer and Environmental Regulation in a Global Economy (Harvard University Press 1995); RD Kelemen, 'Globalizing European Union Environmental Policy' (2010) 17 Journal of European Public Policy 622; C Damro 'Market Power Europe' (2012) 19 Journal of European Public Policy 682. 
ing third countries' regulatory politics, leading either to trade conflicts or the uploading of EU norms, are rather rare, and that the EU is only incidentally a 'Fortress' or 'market power'. ${ }^{2}$ Still others argue that the EU accommodates much more its own regulatory politics to global economic integration and trade rules than is often assumed. ${ }^{3}$

This article looks at this debate, which has only become more topical with the Transatlantic Trade and Investment Partnership (TTIP) negotiations where 'regulatory convergence' is the main objective, from a specific perspective. It starts from the similar question of how the EU assures consistency between its (offensive) trade positions and its (protective) regulatory objectives. To specify the dilemma further: the EU is, on the one hand, one of the most prominent advocates of tackling behind-the-border trade barriers through multilateral and bilateral trade negotiations and adjudication. But, on the other hand, much of the EU's ambitious regulatory policies are seen by its trading partners as exactly of this type of non-tariff trade barrier that the EU otherwise wants to eliminate. This article asks how the EU tries to ensure that it acts consistently ${ }^{4}$ before the World Trade Organization (WTO) judicial bodies, and focuses on disputes about sanitary and phytosanitary and technical measures. It will be shown that, after some years of experiencing how the new regulatory rules of the WTO presented the hardened EU regulatory policies with problems, the EU increasingly tended, first, to consistently refrain from bringing complaints against third countries' environmental, health and safety regulations before the WTO, and, second, as a third party, to consistently side with the defendant. In this way, it avoids accusations of

2 See AR Young, 'The Incidental Fortress: The Single European Market and World Trade' (2004), 42 Journal of Common Market Studies 393; P Müller, Z Kudrna and G Falkner 'EUglobal Interactions: Policy Export, Import, Promotion and Protection' (2014) 21 Journal of European Public Policy 1102.

3 See MP Smith 'Single Market, Global Competition: Regulating the European Market in a Global Economy' (2010) 17 Journal of European Public Policy 936.

4 The assumption that consistency is an objective of the European Union is underpinned by it being mentioned in the Treaties as a general principle of the EU. Cf. art 13(1) TEU and art 7 TFEU. At the same time, it is recognised that the EU does not always succeed in pursuing consistency, including between its trade and regulatory policies. Because different institutional actors have different interests, responsibilities and powers in different policy fields, this may result in sometimes inconsistent positions and policies. For example, until the Lisbon Treaty, the European Parliament was not formally competent in trade policy matters, and could therefore be expected, and indeed observed, to be less sensitive to the external trade effects and WTO compatibility of EU regulatory policies. On the other hand, the European Commission as the sole representative of the EU in international trade negotiations and dispute settlement is very sensitive to the external effects and WTO compatibility of internal EU regulation. See F De Ville, 'Explaining the Genesis of a Trade Dispute' (2012) 34 Journal of European Integration 37; F De Ville, 'European Union Regulatory Politics in the Shadow of the WTO' (2012) 19 Journal of European Public Policy 700; T Perišin, 'EU Regulatory Policy and the WTO' in M Cremona and T Takács (eds), Trade Liberalisation and Standardisation: New Directions in the 'Low Politics' of EU Foreign Policy (Asser Institute 2013). 
only defending 'the right to regulate' when it is in its own interests to do so, and may simultaneously be trying to influence the interpretation of the WTO courts of the regulatory agreements to effectively ensure more autonomy for itself in adopting protective regulations.

The remainder of this article is structured as follows. In section two, I consider the WTO's rules and dynamics as a supervisor of its member states' regulatory politics. I give nuance to the idea that the multilateral trading system is so highly legalised that the only two options for states are to comply with its strict and detailed rules or to undergo retaliatory sanctions. Instead, I argue that the WTO's rules are liable to (unsettled) interpretation, and that these interpretations are influenced through jurisprudence that is itself affected by how states plead in disputes. This makes WTO disputes not only an interesting area to study how the EU wants to avoid being found guilty of inconsistency, but also concerning how it might try to broaden its own space for consistent regulatory and trade policies. This constitutes the analytical framework for section three, where I discuss, necessarily in an abstract way, the EU's conduct in all Sanitary and Phytosanitary (SPS) and Technical Barriers to Trade (TBT) disputes of which it has been part. In section four, I go on to explain the EU's strategy in SPS/TBT disputes. I end with some conclusions and suggestions for further research.

\section{The 'political' nature of WTO regulatory supervision}

This section sets the scene for the remainder of the article. It argues that WTO dispute settlement represents a strategically selective institution that affects member states' strategic behaviour vis-à-vis the organisation's agreements and its judicial bodies' rulings, but is itself also affected by the disputants' strategic behaviour.

The WTO is often considered the world's most legalised multilateral institution. The reasons are that, first, since the conclusion of the Uruguay Round, it has a dispute settlement system whereby disputes are adjudicated by lawyers instead of diplomats, including next to an ad hoc tribunal (called a 'panel' in WTO-speak) a standing Appellate Body (AB). Second, states are, under the WTO Treaty, obliged to comply with WTO Agreements, litigation proceeds automatically and sanctions can be authorised, unless all WTO members reject them. Thus, the WTO scores high on two of the three dimensions that determine the degree of legalisation according to Abbott and others. ${ }^{5}$ However, WTO agreements are less strong as regards precision, the third dimension of the definition.

5 KW Abbott and others, 'The Concept of Legalization' (2000) 54 International Organization 401 . 
This imprecision implies that the WTO judicial bodies have great leeway and responsibility in filling gaps and clarifying vague provisions. Moreover, while WTO member states are in principle legally obliged to comply with their commitments and WTO rules, and the AB can authorise retaliatory sanctions if they fail to bring condemned measures into conformity, in most WTO member states WTO rules and dispute decisions have no direct effect, and states can ultimately decide to accept retaliation instead of complying. ${ }^{6}$ This, of course, raises the possibility of defection, something an international court will want to avoid. According to an extensive literature, international courts have a strong preference to 'have [their] authority accepted and expanded', as Schepel and Wesseling have formulated with regard to the European Court of Justice. ${ }^{7}$

For these reasons, many analysts working in the nexus of international relations and international law have recognised that the WTO judicial bodies are to a considerable extent constrained by politics. ${ }^{8}$ They thus have to act strategically, and adapt their strategic action dynamically. The WTO judicial bodies have to take into account two, sometimes contradictory, pressures. First, there is the legitimacy of their decisions, defined here as the acceptance of their decisions by elected officials. ${ }^{9}$ On the other hand, there is the legal consistency of their rulings, which means being in accord with both the WTO agreements as well as with their own earlier decisions. Thus, the precedential value of decisions has great importance. The WTO judicial bodies have to take into account their own jurisprudence as well as how the membership will react to their decisions.

The story does not end there. Not only do the WTO judicial bodies act strategically, anticipating how states will react to their decisions, but WTO member states act 'in the shadow of the WTO'. This means that they will take into account relevant (and, as explained, often ambiguous) WTO rules, as well as the jurisprudence (if available) of the WTO judicial bodies, when enacting regulations. They will generally want to avoid losing a dispute, because this generates reputation costs as well

\footnotetext{
6 See JH Bello 'Less is More'(1996) 90 American Journal of International Law 416; JH Jackson, The WTO Dispute Settlement Understanding: Misunderstandings on the Nature of Legal Obligation' (1997) 91 American Journal of International Law 60.

7 H Schepel and R Wesseling The Legal Community: Judges, Lawyers, Officials and Clerks in the Writing of Europe'(1997) 3 European Law Journal 165.

8 RH Steinberg, 'Judicial Lawmaking at the WTO: Discursive, Constitutional and Political Constraints' (2004) 98 American Journal of International Law 247. According to Steinberg, 'the Appellate Body is constrained by international legal discourse and politics, as well as constitutional structure'. These three factors are nested: legal discourse is constrained by constitutional rules, which is constrained by politics.

9 DR Kelemen 'The Limits of Judicial Power: Trade-environment Disputes in the GATT/ WTO and the EU' (2001) 34 Comparative Political Studies 622.
} 
as possible economic costs through retaliatory trade sanctions. But they will thereby also anticipate how, given the political circumstances and the state of the legitimacy of the world trading system, third states will react and how they think the WTO judicial bodies will decide. Indeed, also complainant nations will make such strategic considerations, and will often refrain from bringing cases where the violator is likely not to comply with a negative decision by the Appellate Body. ${ }^{10}$ Again, there are several reasons for this. First, when a complainant wins a dispute, the fact that it is authorised to adopt retaliatory measures is less than a reward. This resolution mechanism of the WTO punishes in the first place consumers in the country winning the dispute. Second, states that have an interest in the world trading system will not want to erode its legitimacy by provoking non-compliance through forcing the WTO judicial bodies to adopt a decision that is very unpopular (and unfeasible) in the contravening state. And, third, states will be reluctant to bring before the WTO cases that lead to decisions that might backfire by restricting their own policy space in the future. ${ }^{11}$

Thus, how the EU acts as a complainant, a defendant or as a third party $^{12}$ may influence the interpretation of the extent to which and the conditions whereby domestic regulations are compatible with WTO rules. In this way, the EU has an influence on the autonomy the WTO leaves to its member states' regulatory policies and can thus help expand its own regulatory autonomy.

The SPS and TBT Agreements (hereinafter: SPS and TBT) are considered the two regulatory agreements of the WTO that specify the general obligations of the GATT as well as, especially, the exceptions to these obligations as foreseen in Article XX GATT. The SPS is the agreement on how governments can apply food safety and animal or plant health measures, while the TBT tries to ensure that regulations, standards, testing and certification procedures do not create unnecessary obstacles to trade. The SPS is considered to be more constraining than the TBT (which are both considered to be more restrictive than the GATT ${ }^{13}$ ). Both make

10 G Garrett and JM Smith 'The Politics of WTO Dispute Settlement' (2002) Occasional Paper Series, UCLA <http://escholarship.org/uc/item/4t4952d7> accessed 15 November 2014.

11 AR Young 'Of Executive Preferences and Societal Constraints: The Domestic Politics of the Transatlantic GMO Dispute' (2011) 18 Review of International Political Economy 506.

12 Third parties are all but trivial in WTO disputes. See ML Busch and E Reinhardt, 'Three's a Crowd: Third Parties and WTO Dispute Settlement' (2006) 58 World Politics 446. The conventional wisdom is that third parties signal the preferences of the wider membership of the organisation, thus influencing the strategic behaviour of WTO tribunals.

13 G Marceau and JP Trachtman, 'The Technical Barriers to Trade Agreement, the Sanitary and Phytosanitary Measures Agreement, and the General Agreement on Tariffs and Trade' (2002) 36 Journal of World Trade 811. 
it a positive obligation to choose the least trade-restrictive measure to attain an appropriate level of protection, but only the SPS explicitly regulates risk assessment and requires scientific bases for regulation. Also, in the area of SPS measures, quasi-legislative authority has been given to certain international functional organisations, as members should base their SPS measures on international standards developed by them, while this is not the case for TBT measures. Similarly, the requirement of the SPS to accept foreign regulations as equivalent if the exporting country can prove that its measure achieves the importing country's set level of protection is stronger than the more hortatory obligation of the TBT to give positive consideration to mutual recognition.

Before discussing the EU's involvement in SPS/TBT disputes, I briefly introduce how the WTO settles disputes. When a WTO member state thinks another member has taken action that breaches WTO obligations or commitments, it can lodge a complaint. Subsequently, at the first stage the parties are encouraged to find an amicable solution through consultation and mediation. Only if this fails is a panel set up, issuing a report in half a year's time. This report is adopted unless the full membership rejects it or unless one of the parties appeals against the report on legal grounds. In the case of appeal, the Appellate Body issues a report on these legal objections. Normally, given the strict deadlines for the different stages, a dispute should not take longer than one year and three months. However, at every stage of the procedure, consultation and mediation are still possible. As a consequence, only about one third of the cases pass through the full panel process, while the others are settled out of court or remain in a prolonged consultation phase.

\section{The EU's involvement in SPS and TBT disputes}

This section discusses the EU's positioning in SPS/TBT disputes before the WTO. It will show that the EU stopped attacking third countries' sanitary and phytosanitary and technical regulations in 2003 and has also since the beginning of the 2000s consistently sided with the defendant as a third party. As will be discussed, this cannot be explained by a lack of EU interest in third countries' trade-distorting regulations, as the EU has kept addressing these through other venues within and outside the WTO, most notably within the WTO's non-judicial SPS Committee.

Let me set the scene with some overall figures. The EU has been a complainant in seven SPS/TBT cases. ${ }^{14}$ In total, 13 cases have been lodged against the EU citing the SPS and/or TBT Agreement. The EU has

14 SPS/TBT cases submitted by different countries that have the same object are treated as single cases. All WTO dispute information and documents can be found at <http:/ /wto.org/ english/tratop_e/dispu_e/find_dispu_cases_e.htm\#results> accessed 15 November 2014. 
been a third party in 16 SPS/TBT cases. In sum, 53 cases citing the SPS and/or TBT Agreement had been brought before the WTO judicial bodies until 2014. In two thirds (36) of these cases, the EU was involved as a respondent, complainant or third party. The EU thus plays a significant role in WTO adjudication on regulatory issues, making it highly interesting and relevant to analyse how it tries to have the rules interpreted.

Figure 1. SPS/TBT disputes and EU involvement

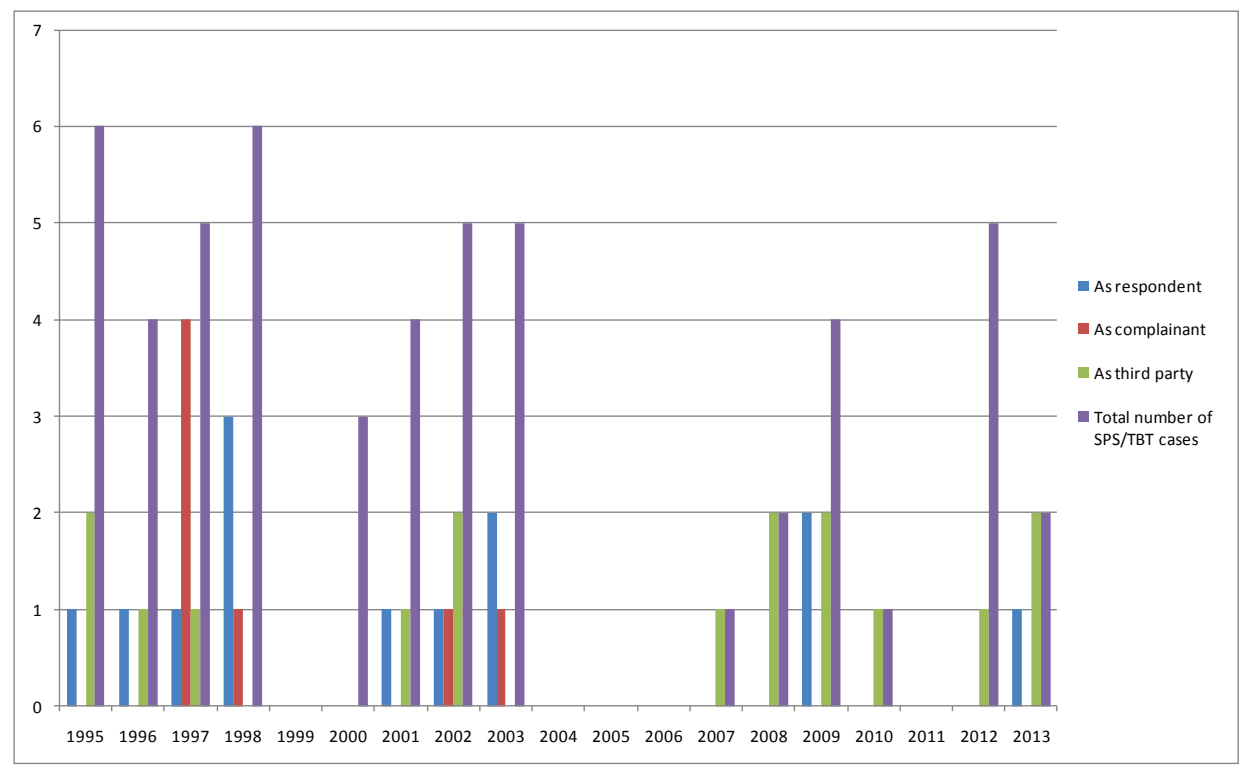

Source: WTO website

What strikes the eye immediately when looking at the evolution of EU involvement in SPS/TBT disputes in this graph is that the EU has not brought a single case citing the TBT and SPS Agreements from 2003 until $2014,{ }^{15}$ while it brought seven SPS/TBT cases before the WTO between the establishment of the Organization in 1995 and 2003. The idleness of

\footnotetext{
15 The data collection and analysis for this article was concluded at the beginning of 2014, thus covering the period 1995-2013. However, after concluding the research, one new SPS/ TBT dispute was launched (in April 2014) at the WTO when the EU requested consultations with Russia concerning certain measures adopted affecting the importation of live pigs, pork and other pig products from the European Union (DS 475). While this dispute could be seen as contradicting the central argument of this paper - without going into the details of the case (which falls outside the scope of the period under analysis) - it seems to be rather exceptional geopolitically and geo-economically in the light of both escalating trade as well as political frictions between the EU and Russia since the latter's accession to the WTO in 2012 (the ban had been imposed by Russia in late January 2014, at the height of the political crisis in Ukraine, and consultations between the EU and Russia on the issue failed in late February 2014, coinciding with the regime change in Ukraine and Crimea).
} 
the EU in lodging SPS and TBT complaints cannot be explained by the relapse of technical and (phyto)sanitary cases in general since the early 2000s. While there was indeed moderation after the first years which witnessed a high number of cases (38 between 1995 and 2003), and a trough in the years 2004-2006, after this period 15 new disputes were lodged. The EU has also not refrained from acting as a third party in SPS and TBT disputes after 2006, and has remained a target for SPS and TBT complaints. Neither has the EU stopped lodging complaints against other WTO members citing WTO agreements other than the SPS or TBT. Nevertheless, there has been a regression: from 63 initiated WTO disputes by the EU between 1995 and 2003 to 26 since 2004. This corresponds to a certain extent to a reversion in the number of WTO disputes in general: 305 between 1995 and 2003 and 164 from 2004 until 2014. This general relapse might be for different reasons. A first one is that the high number of cases in the first years was because countries used the new dispute settlement procedure to clear up some old business. A second reason is that, because of increased judicial restraint exercised by the WTO judicial bodies over the years, countries found it less effective or interesting to bring WTO cases. ${ }^{16}$ When we look at the United States, we see that it has lodged 14 SPS/TBT complaints so far. While indeed these are also rather concentrated in the first years of the WTO's existence (12 until 2004), the US lodged two new complaints in 2009 and 2012.

Whereas alternative explanations for the reticence of the EU in initiating SPS/TBT disputes after 2003 that would apply to the full membership (having cleared up long-running disputes in the first years and increased judicial restraint by the Appellate Body making complaints less interesting) might offer part of the answer to the puzzle of this article, the fact that a number of new SPS/TBT cases have been lodged recently, including by the US, hints at a more EU-specific situation. Another explanation that has to be refuted is that the EU since 2003 has not had any real problems with regulation in third countries and thus has no interest in SPS/TBT complaints, possibly because regulation within the EU has become in many cases more stringent than abroad. This does not seem to be a satisfactory explanation either. Since 2011, the EU has published yearly a trade and investment barriers report. In 2011, 'Regulatory issues - Technical regulations and standards (Technical Barriers to Trade and Sanitary and Phytosanitary issues)' were mentioned as among the 'most important problems European companies face when they want to get access to the markets of $[\ldots]$ strategic

16 I thank Alasdair Young for bringing these points to my attention. 
partners'. ${ }^{17}$ In 2012, some progress was mentioned with India, but it was noted with regard to that country, as well as with Russia, that many outstanding problems remain. Also in its 2013 report, the Commission stated that it 'remains worried about the general approach of India of keeping unjustified and unnecessary SPS measures as a way to maintain its agri-food market closed to imports' while with regard to Russia even new barriers were found. Other evidence that the EU did not become less concerned about foreign SPS/TBT regulations can be found in the SPS Committee's ${ }^{18}$ list of specific trade concerns that WTO members had raised between 1995 and 2012. The EU raised 69 issues during this period, of which 38 before 2004 and 31 since $2004 .{ }^{19}$ Thus, while the EU refrained after 2003 from lodging disputes with the WTO's judicial system, it kept on complaining about third countries' regulations within the SPS (consultative) Committee.

The remainder of this article argues that the EU's reluctance to file complaints against SPS and TBT measures can be explained by its solid position that states should not be too judicially constrained by multilateral rules and rulings in protecting the health and safety of their citizens, as well as the environment. This position is the result of some notorious food safety scandals within the EU coinciding with the EU losing a highprofile WTO case (the Hormones dispute), at a time when an even more controversial dispute (on genetically modified organisms) was looming.

Let us first look at the outcomes and EU behaviour in the SPS/TBT disputes in which the EU has been involved.

17 European Commission, Trade and Investment Barriers Report $(2011,2012,2013)$ available at <http://trade.ec.europa.eu/doclib/press/index.cfm?id=878> accessed 15 November 2014 .

18 The WTO's SPS Committee provides a forum for consultations about food safety and animal or plant health measures that affect trade.

19 WTO, Committee on Sanitary and Phytosanitary Measures, 'Specific Trade Concerns' (2013) Note by the Secretariat, G/SPS/GEN/204, Rev 13. 
Table 1. EU as respondent

\begin{tabular}{|c|c|c|c|c|}
\hline & SPS/TBT & $\begin{array}{l}\text { Year of } \\
\text { initia- } \\
\text { tion }\end{array}$ & Complainants & Outcome \\
\hline $\begin{array}{l}\text { DS } 7 / 12 / 14 \text { EC - Trade } \\
\text { description of scallops }\end{array}$ & TBT & 1995 & $\begin{array}{l}\text { Canada, Peru } \\
\& \text { Chile } \\
\end{array}$ & $\begin{array}{l}\text { Mutually } \\
\text { agreed solution }\end{array}$ \\
\hline DS 26/48 EC - Hormones & SPS/TBT & 1996 & US \& Canada & $\begin{array}{l}\text { Violation } \\
\text { found, retali- } \\
\text { ation }\end{array}$ \\
\hline $\begin{array}{l}\text { DS } 72 \text { EC - Measures af- } \\
\text { fecting butter products }\end{array}$ & TBT & 1997 & New Zealand & $\begin{array}{l}\text { Mutually } \\
\text { agreed solution }\end{array}$ \\
\hline $\begin{array}{l}\text { DS } 134 \text { EC - Restrictions } \\
\text { on certain import duties on } \\
\text { rice }\end{array}$ & SPS/TBT & 1998 & India & $\begin{array}{l}\text { In consulta- } \\
\text { tions }\end{array}$ \\
\hline DS 135 EC - Asbestos & SPS/TBT & 1998 & Canada & $\begin{array}{l}\text { Violation found } \\
\text { but justified } \\
\text { under excep- } \\
\text { tions }\end{array}$ \\
\hline $\begin{array}{l}\text { DS } 137 \text { EC - Measures af- } \\
\text { fecting imports of wood of } \\
\text { conifers }\end{array}$ & SPS/TBT & 1998 & Canada & $\begin{array}{l}\text { In consulta- } \\
\text { tions }\end{array}$ \\
\hline $\begin{array}{l}\text { DS } 231 \text { EC - Trade descrip- } \\
\text { tion of sardines }\end{array}$ & TBT & 2001 & Peru & $\begin{array}{l}\text { Violation } \\
\text { found, mutu- } \\
\text { ally agreed } \\
\text { solution }\end{array}$ \\
\hline $\begin{array}{l}\text { DS } 263 \text { EC - Measures af- } \\
\text { fecting imports of wine }\end{array}$ & TBT & 2002 & Argentina & $\begin{array}{l}\text { In consulta- } \\
\text { tions }\end{array}$ \\
\hline $\begin{array}{l}\text { DS } 290 \text { EC - Protection } \\
\text { of trademarks and geo- } \\
\text { graphical indications for } \\
\text { agricultural products and } \\
\text { foodstuffs }\end{array}$ & TBT & 2003 & Australia \& US & $\begin{array}{l}\text { Violation } \\
\text { found, imple- } \\
\text { mentation }\end{array}$ \\
\hline $\begin{array}{l}\text { DS } 291 / 292 / 293 \text { EC - Bio- } \\
\text { tech products }\end{array}$ & SPS/TBT & 2003 & $\begin{array}{l}\text { US, Canada \& } \\
\text { Argentina }\end{array}$ & $\begin{array}{l}\text { Violation } \\
\text { found, authori- } \\
\text { sation to retali- } \\
\text { ate requested } \\
\text { but proceed- } \\
\text { ings suspended }\end{array}$ \\
\hline $\begin{array}{l}\text { DS } 369 / 400 / 401 \text { EC - } \\
\text { Measures affecting the im- } \\
\text { portation and marketing of } \\
\text { seal products }\end{array}$ & TBT & 2009 & $\begin{array}{l}\text { Canada and } \\
\text { Norway }\end{array}$ & Violation found \\
\hline $\begin{array}{l}\text { DS } 389 \text { EC - Certain meas- } \\
\text { ures affecting poultry meat } \\
\text { products }\end{array}$ & SPS/TBT & 2009 & US & $\begin{array}{l}\text { Panel estab- } \\
\text { lished }\end{array}$ \\
\hline $\begin{array}{l}\text { DS } 459 \text { EU - Certain meas- } \\
\text { ures on the importation and } \\
\text { marketing of biodiesel and } \\
\text { measures supporting the } \\
\text { biodiesel industry }\end{array}$ & TBT & 2013 & Argentina & $\begin{array}{l}\text { In consulta- } \\
\text { tions }\end{array}$ \\
\hline
\end{tabular}


In the SPS/TBT disputes lodged against the EU, violations have been found in six cases, but in one case (Asbestos) this has been permitted under the public health exception of the General Agreement on Tariffs and Trade (GATT Article XX(b)). In Hormones, retaliation has been sanctioned by the Appellate Body. In Biotech products, authorisation to retaliate has been requested but the proceedings have been suspended. In the two other cases that the EU lost, it has implemented the decision or agreed a solution with the complainant. In two other cases, a mutual solution was found before a ruling, and four cases are in the consultations stage (of which three have been there for a long time). For one case, a panel has been established but not yet composed. In the Seal Products case, the panel determined that the exceptions of the EU Seal Regime (for indigenous communities and maritime resource management), but not per se the Regime as such, violate TBT Article 2.1 (non-discrimination). Both Canada and the EU decided to appeal to the AB. The Appellate Body $^{20}$ has largely upheld the Panel's finding, raising concerns about the way in which the exception from the ban for indigenous hunting has been implemented, but in general affirming that the measure is necessary to protect public morals.

I lack the space in this article to discuss the EU's arguments in all these disputes, ${ }^{21}$ so I will concentrate on the main lines of defence in the most controversial cases. In the Hormones cases, the EU argued before the panel that 'WTO dispute settlement panels were not competent to judge its level of sanitary protection nor the scientific evidence upon which it was based, but only whether its measures were in conformity with the provisions of the SPS Agreement'. ${ }^{22}$ It also claimed that its measures were based on the precautionary principle and that the US had failed to discharge its burden of proof because it failed to show that the measures at issue were more trade-restrictive than necessary. The EU claimed also that as the measures did not violate the SPS, they were also in conformity with the GATT. Eventually, the EU lost the dispute as the panel concluded that its measures were not based on a risk assessment (Article 5.1 SPS), resulted in arbitrary or unjustifiable distinctions in the levels of sanitary protection (Article 5.5), and were not based on international standards (Article 3.1) without justification (Article 3.3). The EU appealed the ruling, claiming inter alia that: the panel erred in its allocation of the burden of proof under the SPS agreement in finding that it rests on the member imposing a measure; it erred by not according deference to the appropriate level of protection, the scientific assessment

\footnotetext{
20 See WT/DS400/AB/R and WT/DS401/AB/R (May 22, 2014).

${ }^{21}$ For example, the panel report in Biotech Products alone fills more than one thousand pages.

${ }^{22}$ WTO, 'EC Measures Concerning Meat and Meat Products (Hormones) - Complaint by the United States: Report of the Panel' (1997) WT/DS26/R/USA.
} 
and management and adherence to the precautionary principle of the EC measures; panels should adopt a deferential reasonableness when reviewing a member's assessment of scientific evidence; and the panel erred in considering that the precautionary principle was only relevant for provisional measures (WTO 1998: 4-15). The AB sided with the EU on the issue of the burden of proof, but upheld the panel's conclusions that the precautionary principle would not override other obligations and that the EU's measures were inconsistent with Articles 3.3 and 5.1 SPS.

In the Biotech dispute, the EU generally argued that 'the approach ... has been fully consistent with evolving and applicable international standards, and any finding to the contrary would seriously undermine the effectiveness of these standards, which are premised on the application of a prudent and precautionary approach' and that it believes 'that its actions have been and are those of a prudent government'. ${ }^{23}$ The panel found that the EU applied a de facto moratorium and had consequently acted inconsistently with Article 8 SPS because this caused undue delays in the completion of approval procedures. With regard to product-specific measures, inconsistency with Article 8 SPS was also found, while with regard to EU Member State safeguard measures, inconsistency with Articles 5.1 (risk assessment) and 2.2 (scientific evidence) was recorded.

Table 2. EU as complainant

\begin{tabular}{|l|c|c|l|}
\hline & SPS/TBT & $\begin{array}{c}\text { Year of } \\
\text { initiation }\end{array}$ & \multicolumn{1}{|c|}{ Outcome } \\
\hline $\begin{array}{l}\text { DS 77 Argentina - Measures af- } \\
\text { fecting textiles, clothing and foot- } \\
\text { wear }\end{array}$ & TBT & 1997 & Withdrawn \\
\hline $\begin{array}{l}\text { DS 85 US - Measures affecting } \\
\text { textiles and apparel products }\end{array}$ & TBT & 1997 & $\begin{array}{l}\text { Mutually agreed } \\
\text { solution }\end{array}$ \\
\hline $\begin{array}{l}\text { DS 96 India - Quantitative restric- } \\
\text { tions on imports of agricultural, } \\
\text { textile and industrial products }\end{array}$ & SPS & 1997 & $\begin{array}{l}\text { Mutually agreed } \\
\text { solution }\end{array}$ \\
\hline $\begin{array}{l}\text { DS 100 US - Measures affecting } \\
\text { imports of poultry products }\end{array}$ & SPS/TBT & 1997 & In consultations \\
\hline $\begin{array}{l}\text { DS 151 US - Measures affecting } \\
\text { textiles and apparel products (II) }\end{array}$ & TBT & 1998 & $\begin{array}{l}\text { Mutually agreed } \\
\text { solution }\end{array}$ \\
\hline $\begin{array}{l}\text { DS 279 India - Import restrictions } \\
\text { maintained under the export and } \\
\text { import policy 2002-2007 }\end{array}$ & SPS/TBT & 2002 & In consultations \\
\hline $\begin{array}{l}\text { DS 287 Australia - Quarantine } \\
\text { regime for imports }\end{array}$ & SPS & 2003 & $\begin{array}{l}\text { Mutually agreed so- } \\
\text { lution }\end{array}$ \\
\hline
\end{tabular}

${ }^{23}$ WTO, 'European Communities - Measures Affecting the Approval and Marketing of Biotech Products: Reports of the Panel' (2006) WT/DS291/R. 
In the cases where the EU cited SPS or TBT articles as a complainant, none has reached the stage of a formal ruling. ${ }^{24}$ The EU has withdrawn one case, found a mutually agreed solution in four instances, while two disputes have remained for a long time at the stage of consultations. It should also be mentioned that only DS 100 and DS 287 can actually be considered as 'genuine' regulatory disputes, the others revolving around rules of origin, duties or quantitative restrictions. DS 100 concerns one of the many battles in the Transatlantic 'chicken war' that dates back to the 1960s. In the mid-1990s, the EU and the US tried to find Veterinary Equivalence Agreements. When this attempt failed for poultry, the US retaliated against stringent EU poultry standards (basically prohibiting the US practice of decontamination with a chlorinated solution) with a ban on poultry imports from the EU. The EU responded by initiating a case at the WTO, but never pushed it through the stage of a ruling, and the parties remain formally 'in consultations' while chicken will be one of the controversial issues within the TTIP. In DS 287, the EU and Australia reached a mutually agreed solution in 2007. This included enhanced transparency of Australia's quarantine regime, principles of treatment for market access applications for the EU, and continued expert discussions, while respecting Australia's appropriate level of protection, legislation and import policy development process.

Table 3. EU as third party

\begin{tabular}{|l|c|c|l|l|}
\hline & SPS/TBT & $\begin{array}{c}\text { Year of } \\
\text { initiation }\end{array}$ & Complainant & $\begin{array}{c}\text { EU sided } \\
\text { (predominantly) } \\
\text { with }\end{array}$ \\
\hline $\begin{array}{l}\text { DS 2 US - Standards for } \\
\text { reformulated and con- } \\
\text { ventional gasoline }\end{array}$ & TBT & 1995 & Venezuela & Complainant \\
\hline $\begin{array}{l}\text { DS 18/21 Australia - } \\
\text { Measures affecting the } \\
\text { importation of salmon }\end{array}$ & SPS & 1995 & Canada \& US & Defendant \\
\hline $\begin{array}{l}\text { DS 56 Argentina-Meas- } \\
\text { ures affecting the im- } \\
\text { ports of footwear, tex- } \\
\text { tiles apparel and other } \\
\text { items }\end{array}$ & TBT & 1996 & US & Complainant \\
\hline $\begin{array}{l}\text { DS 76 Japan - Meas- } \\
\text { ures affecting agricul- } \\
\text { tural products }\end{array}$ & SPS & 1997 & US & Complainant \\
\hline $\begin{array}{l}\text { DS 237 Turkey - Certain } \\
\text { import procedures for } \\
\text { fresh fruit }\end{array}$ & SPS & 2001 & Ecuador & $\begin{array}{l}\text { (Mutually agreed } \\
\text { solution) }\end{array}$ \\
\hline
\end{tabular}

${ }_{24}$ It seems that the EU has initiated some cases where it cited SPS/TBT articles as leverage to reach a mutually agreed solution. This succeeded in the majority of cases. 


\begin{tabular}{|c|c|c|c|c|}
\hline & SPS/TBT & $\begin{array}{c}\text { Year of } \\
\text { initiation }\end{array}$ & Complainant & $\begin{array}{c}\text { EU sided } \\
\underset{\text { with }}{\text { (predominantly) }}\end{array}$ \\
\hline $\begin{array}{l}\text { DS } 245 \text { Japan - Meas- } \\
\text { ures affecting the impor- } \\
\text { tation of apples }\end{array}$ & SPS & 2002 & US & Defendant \\
\hline $\begin{array}{l}\text { DS } 270 \text { Australia - Cer- } \\
\text { tain Measures affecting } \\
\text { the importation of fresh } \\
\text { fruit and vegetables }\end{array}$ & SPS & 2002 & Philippines & $\begin{array}{l}\text { Panel established } \\
\text { but not yet } \\
\text { composed }\end{array}$ \\
\hline $\begin{array}{l}\text { DS } 367 \text { Australia - } \\
\text { Measures affecting the } \\
\text { importation of apples } \\
\text { from New Zealand }\end{array}$ & SPS & 2007 & New Zealand & Defendant \\
\hline $\begin{array}{l}\text { DS } 381 \text { US - Measures } \\
\text { concerning the importa- } \\
\text { tion, marketing and sale } \\
\text { of tuna and tuna prod- } \\
\text { ucts }\end{array}$ & TBT & 2008 & Mexico & Defendant \\
\hline $\begin{array}{l}\text { DS 384/386 US - Cer- } \\
\text { tain country of origin } \\
\text { labelling (Cool) require- } \\
\text { ments }\end{array}$ & SPS/TBT & 2008 & $\begin{array}{l}\text { Canada \& } \\
\text { Mexico }\end{array}$ & Defendant \\
\hline $\begin{array}{l}\text { DS } 391 \text { Korea - Meas- } \\
\text { ures affecting the im- } \\
\text { portation of bovine meat } \\
\text { and meat products }\end{array}$ & SPS & 2009 & Canada & Defendant \\
\hline $\begin{array}{l}\text { DS } 392 \text { US - Certain } \\
\text { measures affecting im- } \\
\text { ports of poultry from } \\
\text { China }\end{array}$ & SPS & 2009 & China & Defendant \\
\hline $\begin{array}{l}\text { DS } 406 \text { US - Measures } \\
\text { affecting the production } \\
\text { and sale of clove ciga- } \\
\text { rettes }\end{array}$ & SPS/TBT & 2010 & Indonesia & Defendant \\
\hline $\begin{array}{l}\text { DS } 430 \text { India - Measures } \\
\text { concerning the importa- } \\
\text { tion of certain agricul- } \\
\text { tural products from the } \\
\text { US }\end{array}$ & SPS & 2012 & US & $\begin{array}{l}\text { (Panel } \\
\text { established } \\
\text { but not yet } \\
\text { composed) }\end{array}$ \\
\hline $\begin{array}{l}\text { DS } 434 / 435 \text { Australia } \\
\text { - Certain measures con- } \\
\text { cerning trademarks and } \\
\text { other plain packaging } \\
\text { requirements applicable } \\
\text { to tobacco products and } \\
\text { packaging }\end{array}$ & TBT & 2012 & $\begin{array}{ll}\text { Ukraine } & \& \\
\text { Honduras } & \end{array}$ & $\begin{array}{l}\text { (Panel } \\
\text { established } \\
\text { but not yet } \\
\text { composed) }\end{array}$ \\
\hline $\begin{array}{l}\text { DS } 447 \text { US - Measures } \\
\text { affecting the importation } \\
\text { of animals, meat and } \\
\text { other animal products } \\
\text { from Argentina }\end{array}$ & SPS & 2012 & Argentina & $\begin{array}{l}\text { (Panel composed, } \\
\text { no report yet) }\end{array}$ \\
\hline
\end{tabular}


How does the EU position itself as a third party in SPS/TBT disputes? When a dispute leads to a formal ruling, we know how the EU has argued regarding the case, because the panel (and, if appealed, the $A B)$ report extensively summarises third party submissions. The EU has been a third party in 11 SPS/TBT disputes that have led to a formal ruling. Only in three early cases (DS2, 54 and 76) has the EU sided with the complainant, while in the other cases it sided predominantly with the defendant. ${ }^{25}$ In DS 2, the EU argued that the measure under consideration was not proportionate and did not meet the necessity test of Article XX GATT 1994. DS 56 did not really concern a TBT dispute but was rather on specific duties imposed by Argentina exceeding its bound rate for the products concerned. In DS 76, what should surprise us more than the fact that the EU sided with the complainant, the US, is that the EU did not opt to act itself as a complainant, given that the EU also has important commercial interests in exporting agricultural products to Japan. And also in this case, the EU sided with the defendant on important legal issues, such as that the burden of proof should be with the complainant. In the other cases, the EU consistently defended the right of the defendant to choose an appropriate level of protection and the right to take a precautionary or preventive approach. ${ }^{26}$ The EU mainly intervenes, on the side of the defendant, to preserve the discretion of states to regulate, which may be illustrated with an excerpt from its submission in DS 367:

Indeed, an over-extensive interpretation of the role of WTO judicial bodies in SPS disputes would risk to impinge upon the role of national authorities when determining their ALOP. On this point, the European Communities largely agrees with the legal considerations developed by Australia on the issue of the standard of review. Therefore, the European Communities urges the Panel to be conscious of the scope and limits of the role attributed to it under the Understanding on rules and procedures governing the settlement of disputes (the DSU) and the SPS Agreement. ${ }^{27}$

Another interesting example is DS 392 (US - poultry from China), which is of course an especially interesting case as it relates to the longstanding quarrels between the EU and the US on chicken, making it even more surprising that the EU made statements supporting the US

\footnotetext{
25 Also in DS 384, the EU ruled that the conclusion could be that the measure was inconsistent (with art 2.2 TBT), but on a very limited basis, while it sided with the defendant (the US) on most other issues.

${ }^{26}$ Again, it is impossible to discuss the EU position in detail in every dispute; instead, I summarise the EU position and give two notable examples.

${ }^{27}$ WTO, 'Australia - Measures Affecting the Importation of Apples from New Zealand: Report of the Panel' (2010) WT/DS367/R.
} 
position. ${ }^{28}$ In the case, one of the key issues was if a US 'pause' in the establishment and implementation of measures that would allow Chinese poultry to be imported into the US constituted an undue delay (and hence a violation of Article 8 SPS as with EU - Biotech) or a provisional, precautionary measure allowed under Article 5.7 SPS, which the EU used, unsuccessfully, as an affirmative defence in Hormones and Biotech. While the EU noted an absence of information and interpretation from both sides, it noted that the possibility of a defence of the measures under Article 8, Annex C.1(a) or Article 5.7 could not be ruled out.

To sum up, the EU has not been a complainant in any SPS/TBT dispute that reached the stage of a formal ruling and stopped lodging complaints against sanitary, phytosanitary or technical regulations or standards after 2003 until 2014. The EU has been an active third party in SPS/TBT disputes, where it has mostly sided with the defendant, except for three early disputes. We can thus conclude that the EU has been very reluctant to use the SPS and TBT Agreements to contest third country regulations for consumer protection, health and environmental protection purposes. This inclination has only been strengthened since the final years of the 1990s. Since 2002 the EU has mainly sided with the defendant as a third party in SPS/TBT disputes.

In the next section I analyse the rationale behind this reluctance of the EU to file complaints against SPS/TBT measures and its siding with the defendant as a third party and why the period 2002/2003 is a turning point.

\section{Explaining the EU's approach to SPS/TBT disputes}

Why has the EU stopped attacking SPS/TBT measures of third countries before the WTO judicial bodies, and why has it sided with parties defending such measures, notwithstanding continuous frustration by EU exporters and trade officials with a significant number of such non-tariff barriers (see section 3)? This section argues that by not judicially complaining against SPS/TBT measures, the EU wanted to avoid being accused of 'hypocrisy' (or double standards) when it argues as a defendant for the Union's own discretion to decide on its appropriate level of protection (ALOP) and the way to attain it. This defensive position has been strengthened after losing two controversial disputes before the WTO: Hormones and GMOs.

In early 1998, thus around the circulation of the $A B$ report in the Hormones dispute, and as an 'opening salvo in the simmering dispute

\footnotetext{
28 WTO, 'United States - Certain Measures Affecting Imports of Poultry from China: Report
} of the Panel' (2010) WT/DS392/R. 
over GMOs', ${ }^{29}$ the then EU agricultural commissioner Franz Fischler stated that the EU would like to renegotiate the SPS to permit trade restrictions for reasons of 'consumer preference'. The special agricultural negotiator for the US Trade Representative Peter Scher replied that for the US '[t]here are few higher priorities than fighting this very disturbing proposal'. ${ }^{30}$ The EU had unsuccessfully tried to insert 'genuine consumer concerns' $^{\prime 31}$ as a legitimate criterion on which to base SPS measures in the agreement during the Uruguay Round, against the opposition of the US that ultimately prevailed. ${ }^{32}$ The EU did not press the issue because 'many of the food safety scandals that ... hardened EU preferences ... took place after the SPS agreements' and therefore 'the SPS agreement was a low-priority issue for the EU during the Uruguay Round'. ${ }^{33}$

As the EU agreed without much reflection to a rather strict SPS with which it would rapidly come into conflict after certain food scandals made EU consumers risk-averse and keen for more protective regulations, it had to seek a new strategy to defend its hardened position before the judicial bodies of a multilateral institution it was very supportive of. Since then it has tried to stretch the interpretation of the WTO agreements, the SPS agreement in particular, so that they leave more autonomy for states to decide on their ALOP, how this ALOP has to be (scientifically) justified (including the meaning of 'rational relationship' between risk assessment and the measure in question ${ }^{34}$ ), and who shoulders the burden of proof in a dispute. ${ }^{35}$ The EU is mainly trying to persuade the AB to view the precautionary principle as a general principle of international law in the light of which all provisions of the SPS should be interpreted, rather than being just one of the articles (Article 5.7 SPS), and a strictly circumscribed one, that does not override other specific obligations contained in other articles of the SPS.

That the EU shifted so much to the 'protective' side of the continuum before the WTO after 2003 can be understood as follows. It had lost

\footnotetext{
29 JD Gaisford and others, The Economics of Biotechnology (Edward Elgar 2001).

30 WA Kerr, 'International Trade in Transgenic Food Products: A New Focus for Agricultural Trade Disputes' (1999) 22 The World Economy 245.

31 And also animal welfare and environmental concerns.

32 G Skogstad 'The WTO and Food Safety Regulatory Policy Innovation in the European Union' (2001) 39 Journal of Common Market Studies 485.

33 D Drezner, All Politics is Global: Explaining International Regulatory Regimes (Princeton University Press 2007).

34 As elaborated in DS 26 (EC - Hormones) Appellate Body Report.

35 During the negotiations of the SPS agreement, the US and the EU disagreed on whether the importing country that imposes an SPS measure or the exporting country had the onus of proving its (un)safety. The EU believed that the burden of proof should remain with the marketing country, while the US thought the opposite. According to Skogstad (n 32), the US largely prevailed in the negotiations. In the meantime, the WTO judicial bodies have shifted the burden of proof to a large extent to the complainant party.
} 
the sensitive Hormones dispute amidst food scares, ${ }^{36}$ leading to a loss of confidence in EU risk regulation (and even in EU institutions in general). The Commission adopted a communication embracing the precautionary principle and a white paper on food safety in 2000, and in 2003 the European Food Safety Authority was created. Finally, in 2003, the US (with Canada and Argentina) eventually initiated a dispute against the EU's GMO regime that had wide public support. The EU's reaction to this was, as shown in this article, not only to stop initiating SPS/TBT disputes itself, but to support a broad interpretation of the precautionary exception within the WTO by supporting it not only as a defendant but also as a third party.

The SPS Agreement recognises, in its Article 5.7, the precautionary principle in all but name, although only under insufficient scientific evidence, on a provisional basis and on the condition of the pursuit of fuller scientific assessment, leaving room for (restrictive) interpretation. The AB in its ruling in EC - Hormones indeed stated (para 124) that the precautionary principle does not, by itself, and without a clear textual directive to that effect, relieve a panel from the duty of applying the normal (ie customary international law) principles of treaty interpretation in reading the provisions of the SPS Agreement', as later also recalled by the panel in EC - GMOs. Thus, if another article of the SPSA is violated (eg scientific risk assessment), Article 5.7 or the precautionary principle in general cannot save a member state.

As previously said, the European Commission issued its Communication on the precautionary principle in 2000. But the precautionary principle did not help the EU a couple of years later to defend its GMO regime. The EU, as explained above, lost the GMO dispute. While deciding against the EU on rather narrow grounds, the panel also confirmed the AB's systemic interpretation in EU - Hormones that the precautionary principle does not relieve member states of complying with the other obligations (risk assessment, scientific justification) of the SPS.

It seems that, while carrying on the fight to have a broad interpretation of the precautionary principle within the WTO, the EU is trying another justification of stringent regulation that it did not get accepted during the Uruguay Round: collective preferences.

At the end of his term as Trade Commissioner, and rather on a personal note, Pascal Lamy proposed to introduce a special safeguard clause for 'collective preferences'. 37 This safeguard clause would have to be ac-

\footnotetext{
36 For an impressive list of food scares between 1998 and 2006, see T Knowles, R Moody and MG McEachern 'European Food Scares and their Impact on EU Food Policy' (2007) 109 British Food Journal 43.

37 P Lamy, The Emergence of Collective Preferences in International Trade: Implications for Regulation Globalisation' (speech at the Conference on Collective Preferences and Global
} 
companied by two conditions: it would be necessary to demonstrate that there is a coherent underlying social demand and that the adopted measure is consistent with that demand; and it would be necessary to demonstrate that the measure does not restrict trade more than other measures that satisfy the same demand. The EU's ban on trade in seal products tries to get this principle recognised in the international trading system.

In 2009, the EU banned the import and marketing of seal products, with a derogation for traditional hunting by Inuits. ${ }^{38}$ The EU has been taken to the WTO dispute settlement body by Canada and Norway and has defended its decision on 'public moral' grounds (Article XX(a)). The WTO dispute settlement organs were thus required to consider non-instrumental rationales as a distinct basis for trade restrictive measures. ${ }^{39}$

Indeed, the $\mathrm{EU}$, in its submission, defines the policy objective of the measure as follows: 'the EU legislators sought to address the moral concerns of the EU public with regard to the presence on the EU market of seal products' (para 33). The EU, in point 2.5 'Evidence of the public moral concerns' of its first written submission then argues that the large majority in the European Parliament and in the Council, the fact that some Member States had already introduced national bans, and a multi-country survey confirm the sincerity of the public moral concerns, ${ }^{40}$ analogous to the first condition that Lamy had specified in his special safeguard clause proposal. Also, in section 4.4.2, 'The measure is necessary to protect public morals', the EU argues that it is up to complaining parties to identify reasonable available alternatives and that the alternative measures that Canada and Norway have identified are not apt to make an equivalent contribution to the policy objective sought by the regulation, as demanded by the second condition of the Lamy proposal.

In an earlier case (US - Gambling), a panel favoured a dynamic approach to the meaning of 'public morals': 'in the panel's view, the content of these concepts for members can vary in time and space, depending upon a range of factors, including prevailing social, cultural, ethical and religious values' (para 6.46141). The same dynamic approach (or 'evolu-

Governance: What Future for the Multilateral Trading System, Brussels, 15 September 2004).

38 De Ville, 'Explaining the Genesis of a Trade Dispute' (n 4) 37; T Perišin, 'Is the EU Seal Products Regulation a Sealed Deal? EU and WTO Challenges' (2013) 62 International and Comparative Law Quarterly 373.

39 R Howse and J Langille 'Permitting Pluralism: The Seal Products Dispute and Why the WTO Should Accept Trade Restrictions Justified by Noninstrumental Moral Values' (2012) 37 Yale Journal of International Law 367.

40 For a profound critique of the use by the EU of the 'public moral concerns' justification of the ban, see Perišin (n 38).

41 Cf. Howse and Langille (n 39) 413. 
tionary interpretation') has also been noted ${ }^{42}$ with how the WTO judicial bodies interpret the discretion of states to take trade restrictive measures 'relating to the conservation of exhaustible natural resources' (Article $\mathrm{XX}(\mathrm{g})$ GATT). Indeed, while after the Tuna Dolphin cases the view was that the GATT/WTO did not allow unilateral ('extra-territorial') measures designed to pressurise other Member States to change their process and production methods, this was explicitly allowed to promote conservation in the Shrimp/Turtle cases.

Thus, the EU's attempts to stretch the interpretation of the WTO regulatory agreements may not be without merits. It might not be excluded that a relatively broad interpretation of the precautionary principle and/ or of the right of states to restrict trade for genuine collective preferences will gain recognition by the WTO because of the EU's consistent exercise of this discretion and the defence of this before the WTO courts, both as a defendant and third party. The ruling in the Seals dispute will be instructive in this respect.

\section{Conclusion}

This article has addressed the question of how the EU solves the possible contradiction of, on the one hand, being one of the strongest supporters of the multilateral trading system while, on the other, being the most radical regulator in the area of environmental and health protection, leading often to interferences with free trade. The EU was confronted with this tension immediately after the establishment of the WTO when it lost the contentious Hormones dispute amidst food scares in Europe. As had been expected for years, in 2003 its controversial but within Europe widely supported GMO regime was brought before the WTO courts. This article has shown that the EU reacted to these events by ceasing to initiate disputes against third countries' food, environmental and safety regulations, while consistently siding with defendants as a third party in SPS/TBT disputes. The EU thereby mainly promotes the discretion of states in choosing their appropriate level of protection and in adopting a precautionary approach. More recently, it seems that the EU has also taken up again an old but unsuccessful attempt to introduce 'collective preferences' as a legitimate exception within the WTO.

This article's main objective was to portray and explain the EU's behaviour in SPS/TBT disputes in the WTO. It has focused less on the question of how successful the EU's strategy is. However, in the law literature on WTO dispute settlement, we find evidence that the Appellate Body has, in line with the EU's advocacy during the disputes discussed

42 See I Cheyne 'Gateways to the Precautionary Principle in WTO Law' (2007) 19 Journal of Environmental Law 155. 
here, over the years moved towards a balanced, more deferential approach as regards the standard of review that requires panels to apply a procedural review focused on the method through which a measure is decided, rather than on the outcome of the decision. ${ }^{43}$ Further research could examine to what extent and how the EU's behaviour in WTO SPS/ TBT disputes has been influential in this subtle evolution of WTO jurisprudence.

Second, this article has focused on how the EU tries to affect WTO dispute settlement with the aim of broadening its own scope for stringent SPS and TBT measures that are consistent with its WTO obligations. This article has not addressed the question of how the EU, internally, takes WTO rules and jurisprudence into account to avoid adopting WTO-inconsistent decisions that can be challenged and sanctioned in WTO dispute settlement. Future research could process-trace how EU regulation takes WTO rules, but especially jurisprudence, into account in deciding on both regulatory frameworks and concrete measures.

43 Eg MM Du, 'The Rise of National Regulatory Autonomy in the GATT/WTO Regime' (2011) 14 Journal of International Economic Law 639; T Epps, 'Recent Developments in WTO Jurisprudence: Has the Appellate Body Resolved the Issue of an Appropriate Standard of Review in SPS Cases?' (2012) 62 University of Toronto Law Journal 201. 
